\title{
Machiavellianism in Universities: Perceiving Exploitation in Student Networks
}

\author{
Alexandra Bekiari, Kyriaki Spanou \\ Faculty of Physical Education and Sports Science, University of Thessaly, Trikala, Greece \\ Email: sandrab@pe.uth.gr
}

How to cite this paper: Bekiari, A. and Spanou, K. (2018) Machiavellianism in Universities: Perceiving Exploitation in Student Networks. Social Networking, 7, 19-31.

https://doi.org/10.4236/sn.2018.71002

Received: October 16, 2017

Accepted: November 27, 2017

Published: November 30, 2017

Copyright $\odot 2018$ by authors and Scientific Research Publishing Inc. This work is licensed under the Creative Commons Attribution International License (CC BY 4.0).

http://creativecommons.org/licenses/by/4.0/

(c) (i) Open Access

\begin{abstract}
Aim of this article is to examine parameters and types of Machiavellian behavior among students in selected departments. Social network analysis, bivariate analysis and principal component analysis have been implemented. A total sample of 27 students of Business Administration dept. (Thessaly University of Applied Sciences), 63 students of Veterinary dept. and 57 students of Physical Education dept. (University of Thessaly) has been analyzed. Selected results: Male students tend to regard more students as Machiavellians. Female students seem to be more willing to harm others. Male ones are more willing to exploit weaknesses. Tall or heavy students are regarded as quite Machiavellians. Students of urban origin or rich enough seem to adopt a relatively innocent view. Using internet is regarded as an evidence of Machiavellianism. To select friends by appreciating their knowledge capacity is considered to be unrelated to Machiavellianism. Two types of students who are targeted for Machiavellian practices are demarcated: a) "full target" and b) "beneficial target". Two types of Machiavellian students appear: a) "full Machiavellian" and b) "ruthless". A mixed typology of victims and Machiavellians reveals: a) a "targeting and targeted" type, b) a "full target", c) a "beneficial target" and d) a "ruthless". In general, the Machiavellianism seems to be either a generalized strategy or a quite specific one.
\end{abstract}

\section{Keywords}

Machiavellianism, Social Network Analysis, Students

\section{Introduction}

Verbal aggressiveness is a notion quite analogous to Machiavellianism [1]-[7], as it also signifies power relations (imposing and exploiting) [8]-[15]. Verbal aggressiveness has been systemically perceived and analyzed through social net- 
work analysis [16] [17] [18] [19]. In a similar way, Machiavellianism can also be analyzed as a network of exploiting and imposing relations. Without doubt, Machiavellianism was never deemed to be "old-fashioned" since power has never gone "out of fashion". Thus, Machiavellianism is regarded to play a significant role in our contemporary society as it played half-millennium ago [20]. Machiavellianism is considered to be the strategy of social conduct concerning the manipulation of people for personal gain while this is often against the other's self-interest. Although manipulative behavior can be accomplished, to some extent, by everyone, there are some people who are more willing and competent for such behavioral pattern than others [21]. Machiavellianism is reflected in four dimensions: tendency to distrust others, involvement in amoral manipulation, request for control over others and request for status for oneself [22]. A study among medical students revealed that they used more reasoning based on moral ideals compared with reasoning based on personal interest or maintaining social norms [23]. In another research, which was carried out by [24], the efficacy of business ethics intervention was investigated. More specifically, it has been pointed out that between the love of money and unethical behavior was $\mathrm{Ma}$ chiavellianism, which was a mediator of this relationship mostly among male. In addition, it has been suggested that business students considerably changed their conceptions of unethical behavior, reducing their propensity to engage in theft after having received business ethics intervention contrary to psychology students. A study on business and liberal arts students indicated that male students have the tendency to score higher than female students in manipulation testing and confirmed the idea that there is a close relation between Machiavellianism and cosmopolitan orientation [25]. As far as the association between Machiavellianism and self-efficacy of bully/victim cases is concerned, a study was conducted in children from the fourth and sixth grade of primary schools. It was proved that anti-bullying interventions might be of paramount importance not only in case of mastery-oriented motivation but also in case of citizenship and interpersonal relationships aiming at reducing children's aggression-encouraging cognition not to mention the decrease of Machiavellian attitudes [26]. According to [27], new attention was drawn to the controversial issue of instructional influence in the classroom. He supported that students' perceptions of teacher expert power were negatively related to teacher Machiavellianism whereas perceptions of teacher legitimate power were positively related to teacher Machiavellianism.

However, the aforementioned studies have not implemented social network analysis which is the most appropriate tool for exploring relations. Social network analysis has been applied in several studies until now [28] [29]. These studies have focused on aggressiveness and not on Machiavellianism. Machiavellianism can also be explored as a social structure/hierarchy (who concentrates most Machiavellian actions exerted by others, what chains of such actions are successively shaped and who is the final receiver of these). 


\section{Innovation}

Aim of this research is to explore parameters and profiles of Machiavellian (and Machiavellian targets) patterns. The academic added value of this analysis consists in providing first results for a deeper understanding of the Machiavellian behavior and targets profiles a structural phenomenon. The practical added value is expected to relate with the need to distinguish profile groups susceptible to Machiavellianism and to take measures for preventing such behaviors or for protecting possible targets.

\section{Method}

Three students groups (classes) of Higher Education departments of Thessaly, Greece, have been selected as network samples. Particularly, these groups were: a class of the Veterinary dept. $\left(\mathrm{N}_{1}=63\right.$ of the $4^{\text {th }}$ semester- female $=43$, male $\left.=20\right)$ and a class of the Physical Education and Sport Sciences dept. $\left(\mathrm{N}_{3}=57\right.$ of the $4^{\text {th }}$ semester- female $=28$, male $=29$ ) at the University of Thessaly as well as a class of the Business Administration dept. of the Technological Educational Institute of Thessaly $\left(\mathrm{N}_{5}=27\right.$ of the $6^{\text {th }}$ semester- female $=14$, male $\left.=13\right)$. Therefore, the networks totally consisted of 147 nodes. This sample shows the advantage of the variability of the study time (different semesters) and the variability of corporal qualification among the three departments. A research focusing only on Physical Education students' network could be characterized as biased, as this field is considered to be a field quite susceptible to Machiavellianism because of its specific context and content (antagonism in sport games).

Veterinary and Business Administration dept. were selected due to their heterogeneous mentality. Veterinary necessitates higher admission standards than Physical Education. Business Administration cultivates organizational, cultural and social discourse which could be supposed to "refine" the everyday communication and mitigate verbal aggressiveness and bullying. Thus, the whole sample is not so biased as it would be with only Physical Education students. Apart from that, the fact that the whole of networks is a judgment sample and not a random one, this is not a weakness as it aims at analytic statistics and not ate descriptive statistics. Research ethics was observed. Discretion was guaranteed in order to convince the participants to give sincere answers. Only the compiled results are presented and not personal data.

The network-related part of the questionnaire was based on previous tested questionnaires [22] [30]. Questions relevant to Machiavellianism were converted from psychometric from into network form. The non-network part of questionnaire consists in parameters relevant to personal features of students (e.g. travelling experience, age, gender, socio-economic state).

Several network variables (Katz status, indegree, authority, pagerank, outdegree) were used in order to enable a multiple structural exploration. They were calculated with Visone 1.1. Conventional statistics (spearman test) has been applied in order to detect correlations between non-network and network va- 
riables. Such a bivariate analysis enables an overview on all possible relations. Thus, it was preferred to a multivariate analysis [31] [32]. Principal Component Analysis was also implemented in order to reveal behavioral patterns (typology) [33] [34] [35] [36].

\section{Results and Discussion}

The "Diagram 1" shows three examples of networks of a specific Machiavellian behavior (acquiring information for benefit) among students in three different departments of Higher Education in Thessaly, Greece. The density of the Business Administration dept is the highest (5.2\%), while the density of physical education dept is the lowest $(0.6 \%)$. This may be attributed to various parameters, incl. also the mentality cultivated in each dept (e.g. business administration deals with information management and benefit balancing much more than veterinary or physical education dept).
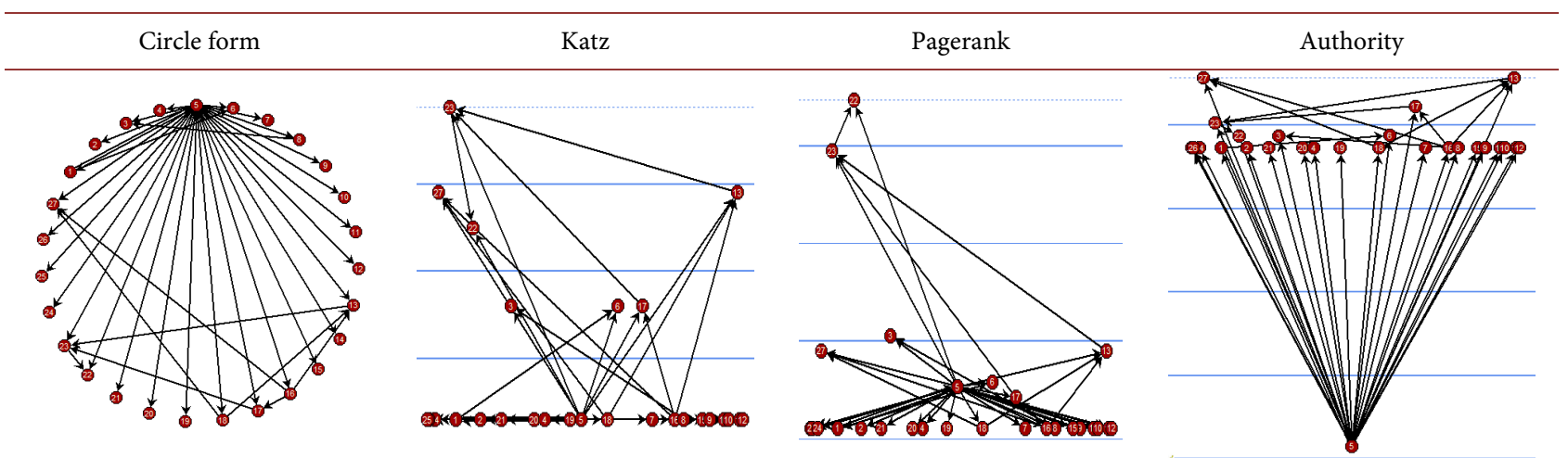

University of Applied Science of Thessaly, Business administration dept., nodes $=27$, links $=37$, density $=5.2 \%$
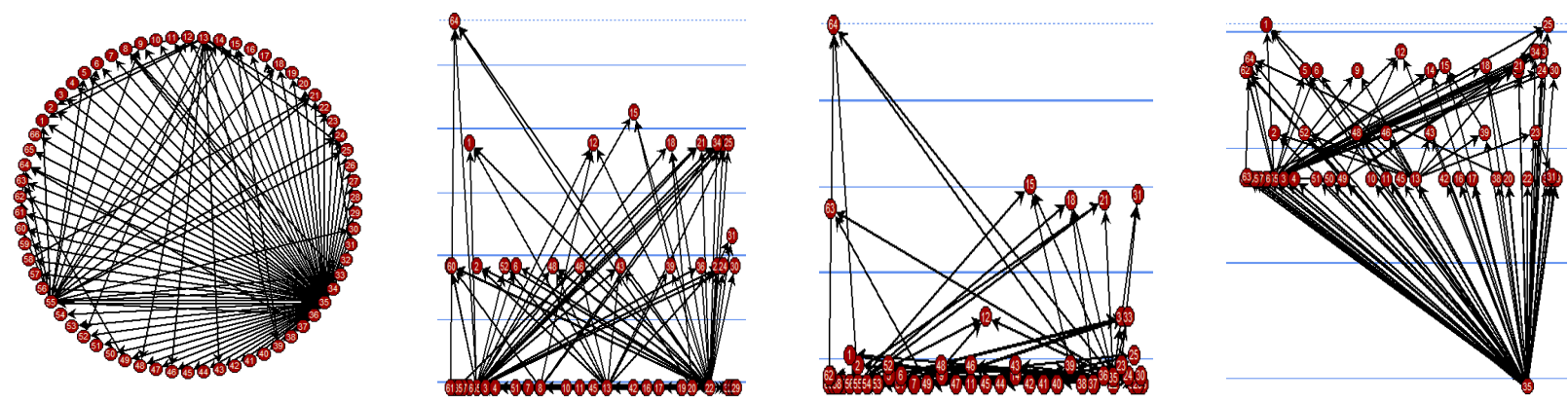

University of Thessaly, Veterinary dept., nodes $=63$, links $=103$, density $=2.4 \%$
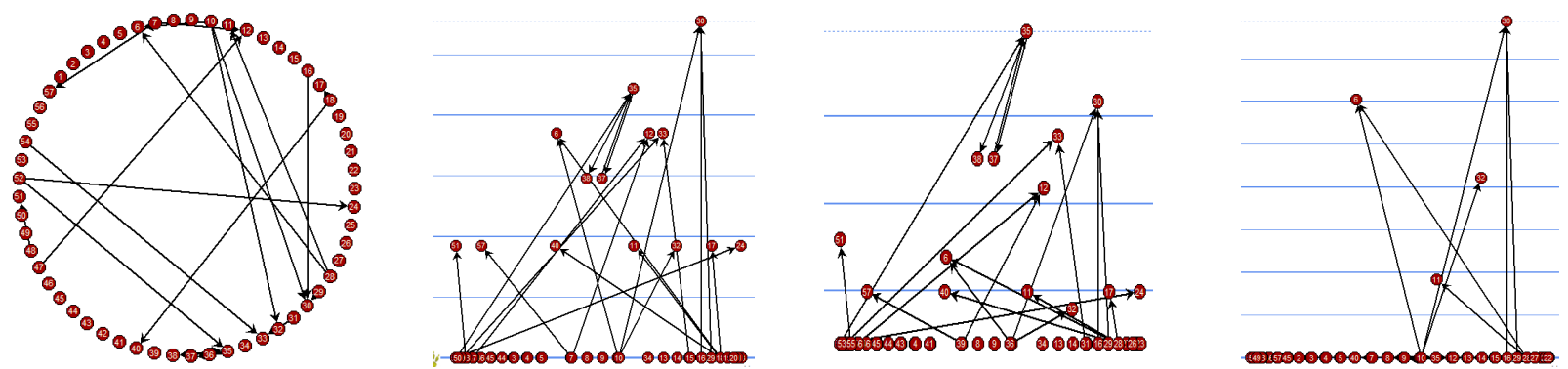

University of Thessaly, Physical education dept., nodes $=57$, links $=20$, density $=0.6 \%$

Diagram 1. Network examples. Relation: Information for benefit. 
In "Table 1", the physical parameters seem to be extensively relevant to the Machiavellianism ascribed. Mainly male students tend to regards more students as Machiavellians while the female students do not maintain so hostile view. Simultaneously, the female students are considered to be willing to harm others for their own benefit. On the other hand, male students are considered to be more willing to exploit weaknesses of others. Thus, gender seems to be relevant to Machiavellian tactics, but different ones. In contrast to the dominant view, the male Machiavellians are expected to use indirect strategy such as exploitation of weaknesses and female ones are supposed to be straighter, as they are expected to harm others. As for the physical appearance, tall or heavy students are regarded are quite Machiavellians in several terms. This can be attributed to the fact that these students attract attention and give the impression that they are more assertive, stronger or more capable of imposing themselves in general. Gender and weight have also been explored in previous studies [37] [38] [39].

In "Table 2", socio-economic parameters also prove to be of relevance for ascribing Machiavellianism to others. Students of rural origin as well as of low economic situation tend to regard others as Machiavellians in terms of trying to benefit themselves by using information or harming. On the contrary, student of urban origin or rich enough seem to adopt a more innocent view. This could be understood as a result of up-bringing and family conditions. Students who have been brought up in a degraded social environment are more likely to maintain a hostile view or even a generalized worldview while those who were always

Table 1. Physical parameters and Machiavellianism.

\begin{tabular}{|c|c|c|c|c|c|c|c|c|c|}
\hline & $\begin{array}{c}\text { rich people_ } \\
\text { outdegree }\end{array}$ & $\begin{array}{l}\text { rich people_ } \\
\text { indegree }\end{array}$ & $\begin{array}{c}\text { rich people_ } \\
\text { status }\end{array}$ & $\begin{array}{c}\text { rich people } \\
\text { pagerank }\end{array}$ & $\begin{array}{l}\text { harm for } \\
\text { benefit_- } \\
\text { outdegree }\end{array}$ & $\begin{array}{l}\text { harm for } \\
\text { benefit_- } \\
\text { authority }\end{array}$ & $\begin{array}{l}\text { weakness_ } \\
\text { indegree }\end{array}$ & $\begin{array}{c}\text { weakness_ } \\
\text { status }\end{array}$ & $\begin{array}{c}\text { weakness_ } \\
\text { pagerank }\end{array}$ \\
\hline \multirow[t]{2}{*}{ gender } & $-0.149\left(^{*}\right)$ & -0.047 & -0.048 & -0.090 & -0.060 & $0.131\left(^{*}\right)$ & -0.009 & -0.014 & $-0.132\left(^{*}\right)$ \\
\hline & 0.020 & 0.467 & 0.455 & 0.162 & 0.347 & 0.041 & 0.888 & 0.829 & 0.038 \\
\hline \multirow[t]{2}{*}{ height } & 0.098 & $0.197\left(^{*}\right)$ & $0.201\left(^{*}\right)$ & $0.224\left(^{*}\right)$ & 0.089 & -0.113 & 0.159 & 0.171 & $0.214\left(^{*}\right)$ \\
\hline & 0.279 & 0.028 & 0.025 & 0.012 & 0.325 & 0.210 & 0.077 & 0.057 & 0.016 \\
\hline \multirow[t]{2}{*}{ weight } & $0.182\left(^{*}\right)$ & 0.087 & 0.083 & 0.159 & $0.186\left(^{*}\right)$ & -0.035 & $0.210\left(^{*}\right)$ & $0.214\left(^{*}\right)$ & $0.240\left(^{* *}\right)$ \\
\hline & 0.044 & 0.338 & 0.364 & 0.079 & 0.040 & 0.704 & 0.020 & 0.018 & 0.007 \\
\hline
\end{tabular}

Significance level: ${ }^{*} p<0.05,{ }^{* *} p<0.01$

Table 2. Socio-economic parameters and Machiavellianism.

\begin{tabular}{ccc}
\hline & info for benefit_outdegree & harm for benefit_outdegree \\
\hline urban residence & 0.077 & $-0.213\left(^{*}\right)$ \\
family economic situation & 0.391 & $\mathbf{0 . 0 1 6}$ \\
& $-\mathbf{0 . 2 5 6}\left(^{* *}\right)$ & -0.039 \\
& $\mathbf{0 . 0 0 4}$ & 0.669 \\
\hline
\end{tabular}

Significance level: ${ }^{*} p<0.05,{ }^{* *} p<0.01$ 
socially and financially comfortable tend to be more unsuspecting. Similar studies have also taken place in verbal aggressiveness [40] [41].

In "Table 3", those who use to travel frequently abroad by plane for sport reasons tend to be more suspecting against others. This can be attributed the fact that they get familiar with more opportunities and perspectives. Thus, they become more ambitious in a cosmopolitan environment and tend to see everywhere "novel" antagonists who try to benefit themselves by using information but not by harming others directly. However, they are likely to be regarded by others as Machiavellians. This is expectable, as Machiavellianism is an option mainly for those who consider themselves to have very restricted opportunities and thus they feel hemmed in, and not so much for those who can frequently travel abroad by plane. In part similar and extensive determinants have been explored in previous research [42].

In "Table 4", students who surf in the internet quite frequently either for study reasons or entertainment are considered to be Machiavellians in terms of using information for their own benefit or try to deceive others. However, such students are not supposed to seek becoming rich. This is understandable, as internet communication is ideal for collecting information or deceiving, but not so much for becoming rich.

"Table 5" shows that the criteria for selecting friends are also related with ascribing Machiavellianism to others as well as with being regarded as Machiavellian. Those who appreciate knowledge capacity on others, they are not suspected by others for Machiavellianism. This is understandable, as such a novel criterion is considered to indicate a quite chaste personality. Those who adopt cleverness as a criterion for selecting friends avoid maintaining a negative view toward

Table 3. Travelling parameters and Machiavellianism.

\begin{tabular}{|c|c|c|c|c|c|c|c|c|c|c|c|c|c|}
\hline & $\begin{array}{c}\text { info for } \\
\text { benefit_- } \\
\text { outdegree }\end{array}$ & $\begin{array}{c}\text { harm for } \\
\text { benefit_- } \\
\text { outdegree }\end{array}$ & $\begin{array}{l}\text { info for } \\
\text { benefit_- } \\
\text { pagerank }\end{array}$ & $\begin{array}{l}\text { info for } \\
\text { benefit_- } \\
\text { authority }\end{array}$ & $\begin{array}{l}\text { deception_- } \\
\text { pagerank }\end{array}$ & $\begin{array}{l}\text { deception_ } \\
\text { authority }\end{array}$ & $\begin{array}{l}\text { control__ } \\
\text { authority }\end{array}$ & $\begin{array}{c}\text { Socialsuccess } \\
\text { _authority }\end{array}$ & $\begin{array}{l}\text { rich people_ } \\
\text { authority }\end{array}$ & $\begin{array}{l}\text { harm for } \\
\text { benefit_- } \\
\text { indegree }\end{array}$ & $\begin{array}{l}\text { harm for } \\
\text { benefit_- } \\
\text { status }\end{array}$ & $\begin{array}{l}\text { harm for } \\
\text { benefit_- } \\
\text { pagerank }\end{array}$ & $\begin{array}{l}\text { harm for } \\
\text { benefit_- } \\
\text { authority }\end{array}$ \\
\hline \multirow[t]{2}{*}{$\begin{array}{l}\text { travel abroad } \\
\text { last } 5 \text { years }\end{array}$} & 0.044 & -0.172 & -0.007 & -0.020 & $-0.197\left(^{*}\right)$ & -0.043 & $-0.181\left(^{*}\right)$ & $-0.197\left(^{*}\right)$ & $-0.180\left(^{*}\right)$ & -0.030 & -0.041 & $-0.185\left(^{*}\right)$ & -0.050 \\
\hline & 0.629 & 0.055 & 0.934 & 0.822 & 0.028 & 0.635 & 0.044 & 0.028 & 0.044 & 0.738 & 0.647 & 0.039 & 0.577 \\
\hline \multirow[t]{2}{*}{$\begin{array}{l}\text { travel abroad } \\
\text { athletic }\end{array}$} & $0.197\left(^{*}\right)$ & $-0.240\left(^{* *}\right)$ & $-0.219\left(^{*}\right)$ & $-0.248(* *)$ & -0.068 & $-0.191\left(^{*}\right)$ & -0.023 & -0.082 & 0.084 & $-0.267(* *)$ & $-0.267(* *)$ & -0.131 & $-0.234\left(^{* *}\right)$ \\
\hline & 0.027 & 0.007 & 0.014 & 0.005 & 0.449 & 0.032 & 0.802 & 0.364 & 0.351 & 0.002 & 0.003 & 0.145 & 0.009 \\
\hline
\end{tabular}

Significance level: ${ }^{\star} p<0.05,{ }^{* *} p<0.01$

Table 4. Internet and Machiavellianism.

\begin{tabular}{cccc}
\hline & info for benefit_authority & deception_authority & rich people_authority \\
\hline surf the net studies & $\mathbf{0 . 2 0 8 ( ^ { * } )}$ & -0.060 & $-0.196\left(^{*}\right)$ \\
& $\mathbf{0 . 0 1 9}$ & 0.502 & $\mathbf{0 . 0 2 8}$ \\
surf the net entertainment & $\mathbf{0 . 2 4 2 ( ^ { * * } )}$ & $\mathbf{0 . 1 9 6 ( ^ { * } )}$ & 0.042 \\
& $\mathbf{0 . 0 0 6}$ & $\mathbf{0 . 0 2 8}$ & 0.641 \\
\hline
\end{tabular}

Significance level: ${ }^{*} p<0.05,{ }^{* *} p<0.01$ 
Table 5. Friendship criteria and Machiavellianism.

\begin{tabular}{cccccc}
\hline & $\begin{array}{c}\text { social success__ } \\
\text { outdegree }\end{array}$ & $\begin{array}{c}\text { harm for } \\
\text { benefit_ } \\
\text { outdegree }\end{array}$ & $\begin{array}{c}\text { weakness_ } \\
\text { outdegree }\end{array}$ & $\begin{array}{c}\text { info for } \\
\text { benefit_ } \\
\text { authority }\end{array}$ & $\begin{array}{c}\text { harm for } \\
\text { benefit_ } \\
\text { pagerank }\end{array}$ \\
\hline filia_gnosis & 0.094 & -0.035 & 0.040 & 0.042 & $-\mathbf{0 . 1 7 6}\left(^{*}\right)$ \\
filia_exipnos_efstrofos & $-\mathbf{0 . 1 8 2}\left(^{*}\right)$ & 0.000 & 0.005 & $\mathbf{0 . 2 0 8}\left(^{*}\right)$ & -0.067 \\
filia_evgenis_filikos & $\mathbf{0 . 0 4 1}$ & 0.998 & 0.958 & $\mathbf{0 . 0 1 9}$ & 0.456 \\
& -0.049 & $-\mathbf{0 . 2 0 1}\left(^{*}\right)$ & $-\mathbf{0 . 2 0 6}\left(^{*}\right)$ & -0.034 & -0.035 \\
& 0.584 & $\mathbf{0 . 0 2 4}$ & $\mathbf{0 . 0 2 1}$ & 0.706 & 0.695 \\
\hline
\end{tabular}

Significance level: ${ }^{\star} p<0.05,{ }^{* *} p<0.01$

Table 6. Typology of targeted students.

\begin{tabular}{ccc}
\hline & "Full target" & "Beneficial target" \\
\hline info.for.benefit.target.sum & $\mathbf{0 . 4 3 0}$ & $\mathbf{0 . 7 5 7}$ \\
deception.target.sum & $\mathbf{0 . 4 7 7}$ & 0.111 \\
orders.target.sum & $\mathbf{0 . 6 6 6}$ & 0.202 \\
control.target.sum & $\mathbf{0 . 8 1 1}$ & -0.254 \\
social.status.target.sum & $\mathbf{0 . 7 7 5}$ & -0.420 \\
rich.people.target.sum & $\mathbf{0 . 7 3 7}$ & -0.483 \\
harm.for.benefit.target.sum & $\mathbf{0 . 4 3 5}$ & $\mathbf{0 . 7 1 3}$ \\
weakness.target.sum & $\mathbf{0 . 7 4 9}$ & 0.085
\end{tabular}

Extraction Method: Principal Component Analysis, 2 components extracted

others. However, others attribute Machiavellianism to them. This is understandable, taking into account that friends' cleverness can be exploited for achieving further personal benefits. In general, the fact that such student is chaste enough so as not to ascribe Machiavellianism to others, but the others attribute Machiavellianism to them indicates the subjective character of Machiavellianism. Machiavellianism seems clearly here to be individual perception rather than any objective concept for characterizing someone. Finally, those who consider politeness as a criterion for selecting friends just present a novel social view, as they tend not to attribute Machiavellianism to others. Therefore, in this case, politeness tends to be authentic and not just a strategic instrument for achieving further benefits.

In "Table 6", two types of students who are targeted for Machiavellian practices are demarcated: a) students who tend to become "full target" of Machiavellians, and b) students who become targets by Machiavellians who aim at certain benefit ("beneficial target"), either by information or even harming. This typology implies that victims of Machiavellians tend to become those who either appear to be in general weak and thus an easy target in multifarious ways, or specifically attractive for certain benefit. Similar studies have also taken place in 
verbal aggressiveness [43] [44].

Respectively, in "Table 7", two types of Machiavellian students appear: a) the "full Machiavellian" who tries to exploit others in any possible way, and b) the "ruthless" who seems to act in selected cases (exploiting others aiming at richness or harming for benefit). Thus, not only being targeted but also targeting others seems to be either a generalized or a strategically selective pattern. This means: either all or certain benefit. In the case of Machiavellians, there seem to be either student who tries everything in order to achieve something ("full Machiavellian") or to aim at quite serious benefit even by harming others ("ruthless"). Similar typologies concerning not Machiavellianism but verbal aggressiveness have already been suggested [45] [46].

In "Table 8", a mixed typology of (possible) victims and Machiavellians reveals: a) a type who tries to exploit and is being exploited ("targeting and targeted"), b) a "full target", c) a "beneficial target" and d) a "ruthless", as these three were described above. The type (a) is a natural type who is involved in the game of exploitation. He is exploited and tires to exploit others in order to balance his position. He exploits others and they try, in turn, to exploit him in order to balance their position. Nevertheless, the appearance of the rest three types (b, $c$ and d) who have already appeared in previous tables indicates that these are quite distinct and stable patterns of social roles. Similar typology has been proposed in previous research [47] [48].

\section{Conclusions}

The networks appear to differ among departments. The Business Administration dept students seem to use i.e. much more information for benefit than other departments. Male students tend to regard more students as Machiavellians. Female students seem to be more willing to harm others. Male ones are more willing to exploit weaknesses. Male Machiavellians are expected to use indirect strategy such as exploitation of weaknesses and female ones are supposed to be straighter. Tall or heavy students are regarded as quite Machiavellians, as they

Table 7. Typology of Machiavellian students.

\begin{tabular}{ccc}
\hline & "Full Machiavellian" & "Ruthless" \\
\hline info_for_benefit_outdegree & $\mathbf{0 . 7 3 7}$ & -0.301 \\
deception_outdegree & $\mathbf{0 . 8 8 0}$ & 0.016 \\
orders_outdegree & $\mathbf{0 . 8 6 1}$ & -0.261 \\
control_outdegree & $\mathbf{0 . 8 7 0}$ & -0.223 \\
social_status_success_outdegree & $\mathbf{0 . 7 8 0}$ & -0.231 \\
rich_people_outdegree & $\mathbf{0 . 6 4 0}$ & $\mathbf{0 . 4 2 7}$ \\
harm_for_benefit_outdegree & $\mathbf{0 . 3 9 9}$ & $\mathbf{0 . 8 3 0}$ \\
weakness_outdegree & $\mathbf{0 . 8 0 7}$ & 0.249 \\
\hline
\end{tabular}

Extraction Method: Principal Component Analysis, 2 components extracted 
Table 8. Typology of targeted and Machiavellian students.

\begin{tabular}{ccccc}
\hline & $\begin{array}{c}\text { “Targeting } \\
\text { and targeted" "Full target" }\end{array}$ & $\begin{array}{c}\text { "Beneficial } \\
\text { target" }\end{array}$ & "Ruthless" \\
\hline info_for_benefit_outdegree & $\mathbf{0 . 6 9 0}$ & -0.272 & 0.060 & -0.238 \\
deception_outdegree & $\mathbf{0 . 8 7 7}$ & -0.148 & -0.066 & 0.021 \\
orders_outdegree & $\mathbf{0 . 7 7 4}$ & -0.411 & 0.085 & -0.183 \\
control_outdegree & $\mathbf{0 . 7 8 8}$ & -0.396 & 0.101 & -0.177 \\
social_status_success_outdegree & $\mathbf{0 . 7 0 9}$ & -0.347 & 0.056 & -0.235 \\
rich_people_outdegree & $\mathbf{0 . 6 5 6}$ & -0.034 & -0.204 & $\mathbf{0 . 3 2 6}$ \\
harm_for_benefit_outdegree & $\mathbf{0 . 4 0 2}$ & -0.039 & -0.076 & $\mathbf{0 . 7 6 9}$ \\
weakness_outdegree & $\mathbf{0 . 7 7 7}$ & -0.205 & -0.184 & 0.201 \\
info.for.benefit.target.sum & 0.233 & $\mathbf{0 . 3 3 5}$ & $\mathbf{0 . 7 5 8}$ & 0.137 \\
deception.target.sum & 0.226 & $\mathbf{0 . 3 9 8}$ & 0.172 & -0.266 \\
orders.target.sum & $\mathbf{0 . 3 5 6}$ & $\mathbf{0 . 5 6 8}$ & 0.196 & 0.233 \\
control.target.sum & $\mathbf{0 . 3 6 4}$ & $\mathbf{0 . 7 3 5}$ & -0.221 & 0.047 \\
social.status.target.sum & $\mathbf{0 . 3 3 3}$ & $\mathbf{0 . 7 2 0}$ & -0.391 & -0.013 \\
rich.people.target.sum & $\mathbf{0 . 3 2 2}$ & $\mathbf{0 . 6 7 6}$ & -0.429 & -0.223 \\
harm.for.benefit.target.sum & 0.206 & $\mathbf{0 . 3 5 4}$ & $\mathbf{0 . 7 1 6}$ & 0.106 \\
weakness.target.sum & $\mathbf{0 . 3 4 6}$ & $\mathbf{0 . 6 4 4}$ & 0.156 & -0.295 \\
\hline
\end{tabular}

Extraction Method: Principal Component Analysis, 4 components extracted

attract attention as more capable of imposing. Students of urban origin or rich enough seem to adopt a relatively innocent view, due to their up-bringing and family conditions. Welfare makes someone more unsuspecting. Cosmopolitan students (traveling frequently abroad by plane) tend to be more suspecting against others, as they are more ambitious and see everywhere "novel" antagonists. Using internet is regarded as an evidence of Machiavellianism, as it is connected with information exploitation. To select friends by appreciating their knowledge capacity is considered to be a chaste option, quite unrelated to Machiavellianism. Adopting cleverness as a value for selecting friends is connected with an innocent view toward others. Politeness as a criterion for selecting friends is related with a novel social view and not with attributing Machiavellianism to others. Machiavellianism seems to be an individual perception rather than any objective concept for characterizing someone. Two types of students who are targeted for Machiavellian practices are demarcated: a) students who tend to become "full target" of Machiavellians, and b) students who become targets by Machiavellians who aim at certain benefit ("beneficial target"). Respectively, two types of Machiavellian students appear: a) the "full Machiavellian" and b) the "ruthless". A mixed typology of (possible) victims and Machiavellians reveals: a) a type who tries to exploit and is being exploited ("targeting and targeted"), b) a "full target", c) a "beneficial target" and d) a "ruthless", as these 
three were described above. Thus, these three are quite distinct and stable patterns of social roles. In general, the Machiavellianism seems to be either a generalized strategy or a quite specific one.

Certain limitations of this study and points for future research consist in the restricted sample which can be extended to more departments and regions. Future results from different scientific milieus and academic communities of various departments or institutes/laboratories within a particular department (concerning not only students but also academic and research staff) could provide more insightful information about Machiavellianism. Further statistical tests like cluster analysis and regression can be applied in order to provide a wider variety of types. Finally, community analysis of networks can be used for detecting dense groups (e.g. modularities) which adopt Machiavellians tactics or relevant value systems.

\section{References}

[1] Bekiari, A., Digelidis, N. and Sakellariou, K. (2006) Perceived Verbal Aggressiveness of Coaches in Volleyball and Basketball: A Preliminary Study. Psychological Reports, 103, 526-530. http://doi.org/10.2466/PMS.103.2.526-530

[2] Bekiari, A., Kokaridas, D. and Sakellariou, K. (2005) Verbal Aggressiveness of Physical Education Teachers and Students' Self-Reports of Behaviour. Psychological Reports, 96, 493-498. http://doi.org/10.2466/pr0.96.2.493-498

[3] Bekiari, A., Kokaridas, D. and Sakellariou, K. (2006) Associations of Students' Self-Reports of Their Teacher's Verbal Aggression, Intrinsic Motivation, and Perceptions of Reasons for Discipline in Greek Physical Education Classes. Psychological Reports, 98, 451-461. http://doi.org/10.2466/PR0.98.2.451-461

[4] Bekiari, A., Patsiaouras, A., Kokaridas, D. and Sakellariou, K. (2006) Verbal Aggressiveness and State Anxiety of Volleyball Players and Coaches. Psychological Reports, 99, 630-634. http://doi.org/10.2466/PR0.99.2.630-634

[5] Bekiari, A. and Sakellariou, K. (2003) Perceived Instructor Verbal Aggressiveness and Student State Learning in Physical Education. Italian Journal of Sport Sciences, 1, 251-256.

[6] Deliligka, S., Bekiari, A. and Syrmpas, I. (2017) Verbal Aggressiveness and Argumentativeness in Physical Education: Perceptions of Teachers and Students in Qualitative and Quantitative Exploration. Psychology, 8, 1693-1717. https://doi.org/10.4236/psych.2017.811112

[7] Hassandra, M., Bekiari, A. and Sakellariou, K. (2007) Physical Education Teacher's Verbal Aggression and Student's Fair Play Behaviors. The Physical Educator, 64, 94-101.

[8] Bekiari, A. (2012) Perceptions of Instructors' Verbal Aggressiveness and Physical Education Students' Affective Learning. Perceptual and Motor Skills, 115, 325-335. http://doi.org/10.2466/06.11.16.PMS.115.4.325-335

[9] Bekiari, A. (2014) Verbal Aggressiveness and Leadership Style of Sports Instructors and their Relationship with Athletes' Intrinsic Motivation. Creative Education, 5, 114-121. http://doi.org/10.4236/ce.2014.52018

[10] Bekiari, A., Koustelios, A. and Sakellariou, K. (2000) Instructors' Verbal Aggressiveness from Universities in Greece. Studi e Ricerche, 5, 225-232.

[11] Bekiari, A. and Manoli, P. (2016) EFL Teacher Verbal Aggressiveness and Argu- 
mentativeness and Student Socio-Affective Strategy Use and Affective Learning: Exploring Possible Associations. Journal of Teacher Education and Educators, 5, 154-171.

[12] Bekiari, A. and Pylarinou, M. (2017) Instructor Argumentativeness and Socio-Communicative Style and Student Discipline: Using Physical Education Students' Class as an Illustration. Open Journal of Social Sciences, 5, 122-136. http://doi.org/10.4236/jss.2017.53011

[13] Bekiari, A. and Syrmpas, I. (2015) Coaches' Verbal Aggressiveness and Motivational Climate as Predictors of Athletes' Satisfaction. British Journal of Education, Society \& Behavioural Science, 9, 318-329. http://doi.org/10.9734/BJESBS/2015/17757

[14] Manoli, P. and Bekiari, A. (2015) EFL Teachers' Verbal Aggressiveness and Students' Intrinsic Motivation and Social-Affective Strategy Use: Investigating Possible Relations. Advances in Research, 5, 1-13. http://doi.org/10.9734/AIR/2015/19692

[15] Syrmpas, I. and Bekiari, A. (2015) The Relationship between Perceived Physical Education Teacher's Verbal Aggressiveness and Argumentativeness with Students' Interpersonal Attraction. Inquiries in Sport \& Physical Education, 13, 21-32.

[16] Bekiari, A. and Hasanagas, N. (2016) Sociological Insights in the Education System: "Unlocking" the Power Relations. Afoi Kyriakidi Editions S.A., Thessaloniki.

[17] Bekiari, A. and Hasanagas, N. (2016) "Educating" in Physical Education. Theoretical Approaches and Practical Inquiries. Afoi Kyriakidi Editions S.A., Thessaloniki.

[18] Bekiari, A. and Hasanagas, N. (2016) Suggesting Indicators of Superficiality and Purity in Verbal Aggressiveness. An Application in Adult Education Class Networks of Prisoners. Open Journal of Social Sciences, 4, 279-292. https://doi.org/10.4236/jss.2016.43035

[19] Bekiari, A. and Pachi, V. (2017) Insights into Bullying and Verbal Aggressiveness through Social Network Analysis. Journal of Computer and Communications, 5, 79-101. https://doi.org/10.4236/jcc.2017.59006

[20] Galie, P.J. and Bopst, C. (2006) Machiavelli and Modern Business: Realist Thought in Contemporary Corporate Leadership Manuals. Journal of Business Ethics, 65, 235-250. https://doi.org/10.1007/s10551-005-5352-1

[21] Wilson, D.S., Near, D. and Miller, R.R. (1996) Machiavellianism: A Synthesis of the Evolutionary and Psychological Literatures. Psychological Bulletin, 119, 285-299. https://doi.org/10.1037/0033-2909.119.2.285

[22] Dahling, J.J., Whitaker, B.G. and Levy, P.E. (2009) The Development and Validation of a New Machiavellianism Scale. Journal of Management, 35, 219-257. https://doi.org/10.1177/0149206308318618

[23] Hren, D., Vujaklija, A., Ivanišević, R., Knežević, J., Marušić, M. and Marušić, A. (2006) Students' Moral Reasoning, Machiavellianism and Socially Desirable Responding: Implications for Teaching Ethics and Research Integrity. Medical Education, 40, 269-277. https://doi.org/10.1111/j.1365-2929.2006.02391.x

[24] Tang, T.L.P. and Chen, Y.J. (2007) Intelligence vs. Wisdom: The Love of Money, Machiavellianism and Unethical Behavior across College Major and Gender. Jour nal of Business Ethics, 82, 1-26. https://doi.org/10.1007/s10551-007-9559-1

[25] Thummel, G.B. (1975) The Machiavellian Tendencies of Business School Students as Related to Those of Liberal Arts Students. Master Thesis, University of Arizona, Arizona. http://hdl.handle.net/10150/554847

[26] Andreou, E. (2004) Bully/Victim Problems and Their Association with Machiavellianism and Self-Efficacy in Greek Primary School Children. British Journal of 
Educational Psychology, 74, 297-309. https://doi.org/10.1348/000709904773839897

[27] Teven, J.J. (2007) Teacher Machiavellianism and Social Influence in the College Classroom: Implications for Measurement. Communication Research Reports, 24, 341-352. https://doi.org/10.1080/08824090701624247

[28] Hasanagas, N., Bekiari, A. and Vasilos, P. (2017) Friendliness to Animals and Verbal Aggressiveness to People: Using Prison Inmates Education Networks as an Illustration. Social Networking, 6, 224-238. https://doi.org/10.4236/sn.2017.63015

[29] Theoharis, D., Bekiari, A. and Koustelios, A. (2017) Exploration of Determinants of Verbal Aggressiveness and Leadership through Network Analysis and Conventional Statistics. Using School Class as an Illustration. Sociology Mind, 7, 27-43. https://doi.org/10.4236/sm.2017.72003

[30] Bekiari, A. and Hasanagas, N. (2015) Verbal Aggressiveness Exploration through Complete Social Network Analysis: Using Physical Education Students' Class as an Illustration. International Journal of Social Science Studies, 3, 30-49. https://doi.org/10.11114/ijsss.v3i3.729

[31] Theoharis, D. and Bekiari, A. (2016a) The Influence of Mathematics and Learning Environment in Verbal Aggressiveness and Interpersonal Relations: A Dynamic Analysis of Social Networks. Proceedings of the 8 th International Congress Mathematical Society, Thessaloniki, 30 March-3 April 2016, 415-428.

[32] Theoharis, D. and Bekiari, A. (2016) Social Networks Analysis of Centrality: Case Study in Leadership Networks. Proceedings of the 33rd Congress Greek Mathematical Society (with International Participation), Chania, 4-6 November 2016, 250-260.

[33] Bekiari, A. (2016) Insights into Instructors' Verbal Aggressiveness and Students' Machiavellianism through Leadership Style and Motivational Climate. European Scientific Journal, 12, 90-110. https://doi.org/10.19044/esj.2016.v12n25p90

[34] Bekiari, A. (2017) Exploring Relations between Instructors' Verbal Aggressiveness and Argumentativeness and Students' Fair Play Behaviours and Machiavellianism. International Journal of Physical Education, 54, 26-39.

[35] Bekiari, A. (2017) Verbally Aggressive Instructors and Machiavellian Students: Is the Socio-Communicative Style an Over-Bridging? Psychology, 8, 1437-1454. https://doi.org/10.4236/psych.2017.810095

[36] Bekiari, A. and Balla, K. (2017) Instructors and Students Relations: Argumentativeness, Leadership and Goal Orientations. Open Journal of Social Sciences, 5, 128-143. https://doi.org/10.4236/jss.2017.57009

[37] Bekiari, A. and Spyropoulou, S. (2016) Exploration of Verbal Aggressiveness and Interpersonal Attraction through Social Network Analysis: Using University Physical Education Class as an Illustration. Open Journal of Social Sciences, 4, 145-155. https://doi.org/10.4236/jss.2016.46016

[38] Theoharis, D. and Bekiari, A. (2017) Applying Social Network Indicators in the Analysis of Verbal Aggressiveness at the School. Journal of Computer and Communications, 5, 169-181. https://doi.org/10.4236/jcc.2017.57015

[39] Theoharis, D. and Bekiari, A. (2017) Cumulative Hierarchy Analysis (Katz Centrality) on Leadership Networks of Learning Communities. Proceedings of the 9 th International Congress Mathematical Society, Thessaloniki, 17-19 March 2017, 285-297.

[40] Hasanagas, N. and Bekiari, A. (2015) Depicting Determinants and Effects of Intimacy and Verbal Aggressiveness Target through Social Network Analysis. Sociology 
Mind, 5, 162-175. https://doi.org/10.4236/sm.2015.53015

[41] Hasanagas, N. and Bekiari, A. (2017) An Exploration of the Relation between Hunting and Aggressiveness: Using Inmates Networks at Prison Secondary School as an Illustration. Social Networking, 6, 19-37. https://doi.org/10.4236/sn.2017.61002

[42] Bekiari, A., Deliligka, S. and Koustelios, A. (2016) Examining Relations of Aggressive Communication in Social Networks. Social Networking, 6, 38-52. https://doi.org/10.4236/sn.2017.61003

[43] Bekiari, A., Deliligka, S. and Hasanagas, N. (2017) Analysing Networks of Verbal Aggressiveness and Motivation. Psychology, 8, 495-515. https://doi.org/10.4236/psych.2017.83031

[44] Bekiari, A., Pachi, V. and Hasanagas, N. (2017) Investigating Bullying Determinants and Typologies with Social Network Analysis. Journal of Computer and Communications, 5, 11-27. https://doi.org/10.4236/jcc.2017.57002

[45] Bekiari, A., Nikolaidou, Z. and Hasanagas, N. (2017) Typology of Motivation and Aggression on the Basis of Social Network Variables: Examples of Complementary and Nested Behavioral Types through Conventional Statistics. Social Networking, 6, 135-147. https://doi.org/10.4236/sn.2017.62008

[46] Bekiari, A. and Petanidis, D. (2016) Exploring Teachers' Verbal Aggressiveness through Interpersonal Attraction and Students' Intrinsic Motivation. Open Journal of Social Sciences, 4, 72-85. https://doi.org/10.4236/jss.2016.412007

[47] Bekiari, A., Hasanagas, N., Theoharis, D., Kefalas, I. and Vasilou, A. (2015) The Role of Mathematical Object and the Educational Environment to Students' Interpersonal Relationships: An Application of Full Social Network Analysis. Proceedings of the 32 nd Congress Greek Mathematical Society (with International Participation), Kastoria, 799-812.

[48] Theoharis, D. and Bekiari, A. (2017) Structural Analysis of Leadership in School Class Networks. Proceedings of the 34th Congress Greek Mathematical Society (with International Participation), Lefkada, 3-5 November 2017, 271-279. 